\title{
Work engagement and meaningful work across generational cohorts
}

\begin{abstract}
Authors:
Crystal Hoole ${ }^{1}$

Jackie Bonnema ${ }^{1}$

Affiliations:

${ }^{1}$ Department of Industrial

Psychology and People

Management, University of

Johannesburg, South Africa

Correspondence to:

Crystal Hoole

Email:

crystal.hoole@gmail.com

Postal address:

PO Box 524, Auckland Park

2006, South Africa

Dates:

Received: 09 Jan. 2015

Accepted: 13 July 2015

Published: 28 Aug. 2015

How to cite this article:

Hoole, C., \& Bonnema, J.

(2015). Work engagement

and meaningful work across

generational cohorts. SA

Journal of Human Resource

Management/SA Tydskrif vir

Menslikehulpbronbestuur,

13(1), Art. \#681, 11 pages.

http://dx.doi.org/10.4102/

sajhrm.v13i1.681

\section{Copyright:}

(C) 2015. The Authors.

Licensee: AOSIS

OpenJournals. This work is

licensed under the Creative

Commons Attribution

License.
\end{abstract}

\section{Read online:}

Scan this QR

code with your

smart phone or

mobile device

to read online.
Orientation: Engaging employees and providing employees with a sense of meaning at work is not a one-size-fits-all approach. Although research has shown that differences between work engagement and meaningful work amongst generational cohorts exist, results are still inconclusive. With age becoming increasingly more important as a diversity factor, a better understanding of the dynamics between work engagement and meaningful work across different generational cohorts is necessary to design the right strategy for each organisation's unique parameters.

Research purpose: The aim of this study was to determine whether there is a relationship between work engagement and meaningful work and whether there are significant variances between the levels of work engagement and meaningful work between different generational cohorts.

Motivation for study: Work engagement has consistently been highlighted by researchers and human resources experts as a recommended solution to provide companies with the upper hand when it comes to creating a competitive edge. Yet, levels of work engagement are far from ideal, requiring intensified efforts to identify solutions towards raising overall engagement levels. In recent years, much of the focus in terms of generating engagement has been aimed in the direction of financial rewards and other benefits; some organisational experts are of the opinion that a shift is occurring towards meaningful work instead of monetary rewards as the driver of engagement. The changing nature of the work landscape also suggests that generational cohorts experience work engagement and meaningful work differently. Understanding these complexities is mandatory in creating solutions towards improving levels of engagement and meaningful work.

Research approach, design and method: A cross-sectional quantitative research approach has been followed. The Utrecht Work Engagement Scale (UWES) and Psychological Meaningful Scale (PMS) were administered to 261 participants across several financial institutions in Gauteng, including three generational cohorts (Baby Boomers, Generation X and Generation Y).

Main findings: A moderate relationship was found to exist between work engagement and meaningful work. The Baby Boomer generation experiences the highest levels of engagement and meaningful work. Significant differences were found between Baby Boomers and Generation X and Baby Boomers and Generation Y. No significant difference were noted between Generation X and Generation Y.

Practical/managerial implications: A one-size-fits-all strategy to improve work engagement and the sense of meaning in work does not exist. Results of this study suggest that various approaches based on the needs of each cohort may be required in order to sustain engagement. Older workers in particular prove to be far more valuable and productive and should be treated with care.

Contribution: Whilst a large amount of information exists in terms of generational cohorts, not all findings are supported by empirical research to link the concept of work engagement to the different generational cohorts. The conventional belief that older people are less engaged and do not find meaning in their work has been proven to be a misconception, which highlights the danger of stereotypical beliefs. The findings suggest that older employees are still very valuable resources and can contribute significantly to the organisation's success, but have different needs and values than other age groups. Customised engagement strategies tailored towards different generational cohorts might be more beneficial.

\section{Introduction}

Work engagement has been hailed by researchers and human resources experts as a solution to improve the overall functioning of organisations and individuals within organisations. Many studies have pointed out that work engagement has become an important predictor 
in determining organisational outcomes and has been associated with business success (Bakker \& Schaufeli, 2008; Bakker et al., 2007; Gallup Consulting, 2008; Schaufeli, 2013).

An engaged workforce may potentially enhance the competitive edge required in the current economic landscape. Whilst high levels of engagement add value, low levels can have a detrimental effect on the bottom line of organisations. According to global reports, disengaged employee-related productivity losses translate into billions of dollars per year (Bates, 2004; Gallup Consulting, 2008). It seems that a gap exists between ideal engagement levels and the realisation thereof. According to research, almost $71 \%$ of organisations include engagement components in their performance measurement tools, but only $35 \%$ consider themselves successful in terms of positive engagement outcomes (Evenson, 2014).

There are various factors that contribute to employees' experience of engagement in the workplace. According to Wrzesniewski, McCauley, Rozin and Schwartz (1997), individuals spend more than a third of their lives engaged in their jobs. Individuals will pursue different work roles throughout their careers which will allow them to better define and discover themselves.

Furthermore, over the last two decades it has also been noted that there has been a shift in psychology towards a more positive approach focusing on people's strengths (Rothmann, 2003; Seligman \& Csikszentmihalyi, 2000). Research has highlighted that engaged employees are more hands-on, dedicated to maintaining a quality performance standard, take responsibility for their own growth and are now more involved in their jobs than ever, utilising every single skill and capability they possess to fulfil the myriad of roles in business (Rothmann \& Rothmann, 2010; Schaufeli, 2013).

One important point that needs to be made is how work engagement is defined. Construct contamination, confusion and redundancy in the field of engagement has been a problem for at least the last three decades since Morrow (1983) called for a moratorium on the further development of work-related constructs. Since then very little has changed, resulting in the erroneous use of interchangeable constructs such as work engagement, employee engagement, employee involvement, commitment, passion, organisational commitment, to name a few (Havenga, Stanz, Visagie \& Wait, 2011; Macey \& Schneider, 2008; Morrow, 1983; Roodt, 2004; Schaufeli, 2013). Although it is not in the ambit of this article to go into the detail of the history of the construct development of work engagement and related constructs, it suffices to say that although ample evidence exists that work engagement is conceptually a unique and independent construct (Bakker \& Demerouti, 2008; Schaufeli, 2013; Sonnentag, 2011), the debate is still ongoing. It is therefore imperative for every study to clearly define how it conceptualises and operationalises its definition of engagement.

For the purpose of this study we therefore define work engagement as 'a positive, fulfilling, work-related state of mind that is characterized by vigour, dedication, and absorption' (Schaufeli, Salanova, González-Romá \& Bakker, 2002, p. 74).

Work engagement could therefore be understood as the underlying energy of the organisation which might be utilised towards organisational success and personal benefits for the individual (Pech \& Slade, 2006). Despite the recognised advantages of high work engagement and meaningful work levels within the workplace, statistics still indicate that actual levels and outcomes are far from ideal.

As work engagement contributes towards overall organisational success, attention needs to be paid to work dimensions that might be related to engagement levels. In recent years, companies have relied on financial rewards and other benefits to elevate engagement levels (Scott \& McMullen, 2010). New arguments are however surfacing to support the notion that meaningful work (rather than monetary rewards) could be employed as the driver of engagement (Wells-Lepley, 2013). Erickson (2011, p. 1) proposes that 'meaning is the new money', indicating that meaningful work instead of higher pay could facilitate more effort from employees. But do we all experience meaning in the same way, and if we do not what does it mean for organisations? Researchers have long argued whether differences exist amongst generational cohorts in terms of what motivates them and drives them to perform optimally (Deal, Altman \& Rogelberg, 2010; Drake, 2012; Kapoor \& Solomon, 2011; Miller, 2008). Recent years have seen trends in older workers working past their normal retirement age (Boone-James, Mckechnie \& Swanberg, 2011; Miller \& Nyce, 2014). Considering stereotypical beliefs that older workers are less engaged than younger workers, issues become more serious. If older workers are going to be in the workforce for a number of additional years, organisations would want them to be as optimal and engaged as possible. If differences between generational cohorts exist, engagement strategies need to be adjusted and customised accordingly.

\section{Literature review}

\section{Relationship between work engagement and meaningful work}

Work engagement is defined by Schaufeli and Bakker (2003) as an energetic connection that exists between employees and their jobs. As a result, engaged employees are more effective and equipped to cope with demanding situations in the workplace. Whilst some schools of thought position engagement as the opposite of burnout (Maslach \& Leiter, 1997), the work of Schaufeli and Bakker views engagement as an independent construct, which presents as an enduring state of mind (Schaufeli et al., 2002). Engaged employees demonstrate vigour, dedication and absorption when executing tasks in the workplace (Schaufeli et al., 2002).

Schaufeli, Taris and Van Rhenen (2008) propose that engagement contains an element of balance and resilience, as engaged employees tend to feel tired when they work hard, but not in a way that was associated with burnout. Engaged 
employees do not develop into workaholics; instead they merely work hard as result of a high internal drive.

Work engagement should not be confused with other constructs, even though some similarities are found when commitment, job satisfaction and involvement are discussed (Maslach, Schaufeli \& Leiter, 2001; Schaufeli, 2013). Work engagement may go far beyond commitment, as it identifies engaged employees as people who are not merely committed or passionate, but people who are fully aligned with the goals of the organisation and who make a distinct effort to contribute (BlessingWhite, 2012). Maslach et al. (2001) are of the opinion that engagement clearly differs from job satisfaction and involvement in terms of personal fulfilment and energy. According to these researchers, fulfilment and energy could be associated with engagement, but could not be observed clearly in the other two constructs. It can therefore be deduced that the concepts (engagement, commitment, satisfaction and involvement) are related, but that engagement contains a deeper dimension of well-being, emotional and behavioural responses, such as experiencing joy and fulfilment at work (Crabtree, 2005; Hallberg \& Schaufeli, 2006; Schaufeli et al., 2002).

Meaningful work originated as a concept from the philosophical principles associated with the meaning of life, as a feeling of purpose in one's overall existence which creates a sense of harmony and completeness (Overell, 2008). Frankl (1984) indicates that the search for meaning is one of the most important motivators during the lifespan of a human being. Meaningful work can then imply that a person would also find a sense of harmony and completeness in their occupational environment.

Kant defines work that provides autonomy, a sufficient income and the opportunity to develop on a moral level as meaningful work (Bowie, 1998). Meaningful work has also been linked to Maslow's (1943) need hierarchy. The hierarchy places self-actualisation at the top of the pyramid, with the underlying principle that when a certain need is fulfilled, another takes its place. A person therefore always strives to become fully realised (Maslow, 1943). According to Overell (2008), this translates into self-actualisation in work and happens when a person assimilates work completely into identity. Kahn (1990) describes meaningfulness at work as the experience that effort is justified and rewarded accordingly.

Various researchers have linked meaningful work to the values and needs of the individual and identify different dimensions of the construct. Chalofsky and Krishna (2009, p. 195) view meaningful work as a state of 'integrated wholeness', where a 'sense of self', 'the work itself' and 'sense of balance' play a role. Lips-Wiersema and Wright (2012, p. 655) identify four dimensions of meaningful work which relate closely to the needs of the individual and the needs of others. These dimensions can be identified as 'developing the self', 'unity with others', 'service to others' and 'expressing full potential'. May, Gilson and Harter (2004) state that the value that a person finds in work is aligned to aspirations and priorities. Meaningful work could also contribute towards a person's sense of security and dignity (Ayers, Miller-Dyce \& Carlone, 2008). Fairlie (2011) identifies meaningful work as the presence of qualities in the workplace or the work itself that is aligned to a person's definition of meaning. Empowerment research in the workplace indicates that successful and committed employees experience feelings of meaningfulness during the execution of tasks (Thomas \& Velthouse, 1990; Tymon, 1988).

On a theoretical level, several researchers have argued that relationships between work engagement and meaningful work exist on multiple levels. For instance, the affective component of engagement presents a link with the search for meaning and purpose. Csikszentmihalyi (1975) wrote about the holistic sensation that people experience a feeling of total involvement: the idea of holism is related to fulfilment, whilst the idea of involvement may refer to a high level of engagement. Holbeche and Springett (2003) argued that people strive towards finding meaning in life and work, and once they are able to find fulfilment from a professional perspective, they tend to experience increased engagement.

Other researchers argue that the experience of meaningful work could be viewed as a moderator to engagement (Anitha, 2014; Dullien, 2012; Macey \& Schneider, 2008; Wells-Lepley, 2013). Hirschi (2012) supports the notion that meaningful work can foster an environment where engagement levels would be higher. Kular, Gatenby, Rees, Soane and Truss (2008) infer that meaningfulness contributes to a positive attitude towards work and can lead to higher engagement levels. Other field experts, such as Koloc (2013), are of the opinion that meaningful work can lure and retain talent. Meaningfulness, safety, and availability contribute to engagement levels according to May et al. (2004). Employees who are able to find alignment between the meaning they derive from their work and their personal views of meaning will tend to be more engaged and more fulfilled (King \& Napa, 1998; Schaufeli et al., 2002).

Not only is meaningfulness one of the conditions for engagement (Kahn, 1990) but it is also one of the largest single predictors of engagement (Fairlie, 2011).

\section{Generational cohorts}

A generational cohort can be described as a group of individuals who share certain life stages and experiences during the same historical time frame (Kowske, Rasch \& Wiley, 2010). Members of a cohort will therefore be born, attend educational institutions, start work, engage in marriage and retire from the workforce during roughly the same period of time. Whilst living within these time frames, members of a generational cohort are exposed to historical happenings and certain phenomena on cultural and social terrains; these experiences influence their thinking and attitudes, and this in turn can impact on their behaviour (Schewe \& Noble, 2000). The generational cohorts that are 
predominantly represented in the current workforce are the Baby Boomers, Generation X and Generation Y.

Baby Boomers can be defined as individuals born between 1946 and 1964, Generation X represents those born between 1965 and 1980 and Generation Y (also known as Millennials) represents those bornbetween 1981 and 1999(Meriac, Woehr\& Banister, 2010).

Each cohort displays certain characteristics and contributes in their own way to the workplace.

\section{Baby Boomers}

Baby Boomers grew up in a time of economic growth and also experienced political and ideological turmoil during the 1960s (Hornbostel, Kumar \& Smith, 2011). The employees in this cohort are currently nearing retirement (Parry \& Urwin, 2009). According to Hornbostel et al. (2011), Baby Boomers are ambitious, highly competitive and work-driven. They place value on being committed to an organisation and will most likely remain at the same place of work for their entire life (Drewery, Riley \& Staff, 2008).

\section{Generation X}

Generation X's members are the children of Baby Boomers, who grew up in an era of significant technological innovation (Wong, Gardiner, Lang \& Coulon, 2008). They are most likely to have experienced minimal supervision whilst their parents were working and are characterised as independent (Hornbostel et al., 2011). Generation X members have been active in the workplace for the past 30 years and make up a large portion of employment statistics. According to Hornbostel et al. (2011), Generation $X$ members carry some of the beliefs of their parents, such as the drive for money, challenge and progressing within their careers, but they also place an emphasis on work-life balance and a more informal work environment. Generation $X$ members are believed to be more flexible than Baby Boomers (White, 2011).

\section{Generation $\mathbf{Y}$}

Generation Y grew up in the age of social media and cyberspace, and has significant advantage over Baby Boomers in terms of being technologically savvy (Deal et al., 2010). Generation Y members are currently entering the world of work; some might have been part of the workforce for the past few years (Parry \& Urwin, 2009). Generation Y members are team players with a strong need to be included in groups. They want to feel valued and recognised within the workplace, grow and learn. If an environment does not provide these types of work values, they will not hesitate to leave the organisation. Generation Y members are inclined to multitask more and to provide their services for the greater good (White, 2011). Wong et al. (2008) hypothesise that Generation $Y$ is bombarded with negative media reports and has been exposed to the failures of previous generations at a much higher level than previous generations.

\section{Generational cohorts, work engagement and meaningful work}

In terms of meaningful work, previous findings suggest that employees' values influence their experience of meaningful work, which, in turn, could have an impact on work engagement levels. But is there a significant difference in the work values and experience of meaningful work between the cohorts? Researchers are not in agreement on the issue. Some believe that variances exist and that employers should build engagement and meaningful work strategies to accommodate the unique generational needs (Drake, 2012; Kunreuther, 2003). According to Kapoor and Solomon (2011), each cohort brings its own contribution to the workplace. Overell (2008) proposes that the life stage of a person has a significant impact on what they want from work in order to find it meaningful. Research suggests that variances might exist amongst cohorts in terms of the conceptualisation of meaningful work during different life stages (Glass, 2007; Miller, 2008). As a result, varying approaches based on the needs of each cohort may be required in order to sustain engagement (AON Hewitt, 2013; Dwyer, 2009; Pitt-Catsouphes \& MatzCosta, 2009; Robinson, Perryman \& Hayday, 2004). Miller (2008) argues that meaning in work is altered as a person gains more experience. Global studies produce conflicting results relating to the generational cohorts and engagement. In regions such as Asia Pacific, Europe, Latin America and North America, Baby Boomers seem to be more engaged than their younger counterparts (AON Hewitt, 2013). In subSaharan Africa, Generation Y presents higher engagement levels than the other two cohorts (Emergent Growth, 2013; Maurer, 2013). In Australia, Baby Boomers and Millennials are identified as the most engaged (Australian Public Service Commission, 2012), in South Africa, Kenexa's (2012) findings identify Generation Y members as displaying the highest level of engagement, whilst Coetzee and De Villiers (2010) indicate that older generations experience higher levels of engagement than Generation Y. These findings indicate the possibility of cultural and regional influences on the development of engagement cultures.

Boone-James et al. (2011) indicate that age groups should be a consideration when studying engagement, a term they very broadly defined as 'the employee's perception of his/ her value to the organization, the employee's loyalty and commitment to the organization, and his/her willingness to contribute to the good of the organization' (p. 11), as they view age as a new factor of diversity, whilst conceding that certain stereotypes may exist. Others feel that no significant differences exist and that minimal effort should be directed towards separate engagement approaches (Deal et al., 2010; Mlodzik \& De Meuse, 2010).

More specific findings have been proposed by various researchers in terms of the perceived differences in work values amongst generations. Kompier (2005) argues that younger workers (Generation $\mathrm{Y}$ ) tend to question the nature of meaningful work at a higher level than their older colleagues. Schaufeli et al. (2002), as well as Coetzee and De 
Villiers (2010), argue that older workers tend to be more engaged. Wong et al. (2008) conclude that Generation X and Generation $Y$ tend to be more ambitious but less optimistic than their counterparts in the Baby Boomer generation.

Generation X and Generation $Y$ are also motivated by greater workplace challenges than the older generation. D'Amato and Herzfeldt (2008) indicate that the younger generations (Generation X and Generation Y) will be more likely to remain connected to their organisation if the opportunity for learning exists, whereas older workers are less focused on learning and more on the development of leadership and commitment. Generation X and Generation Y prefer a collaborative workplace, tend to be more tolerant of diversity and are more inclined to belong to groups than Baby Boomers (Wong et al., 2008). This might be due to the fact that Baby Boomers are approaching the end of their careers and, as a result, are severing their ties with other people who will remain in the workforce. Generation Y members, on the other hand, are just starting to enter the workforce and therefore need to affiliate themselves to become integrated members of the organisation (Wong et al., 2008).

Should variances exist, organisations can tailor their engagement strategies towards this diversity in order to be successful. Kapoor and Solomon (2011) propagate that a level of understanding needs to be created between the members of different generations who share the same workspace. By fostering a generational-friendly environment, organisations are also investing in the development of future leaders (Kunreuther, 2003).

\section{Problem statement and research questions}

The focus of many organisations is shifting towards customising their engagement strategies. Well-informed strategies need to be supported by good research. Work engagement should not be underestimated when it comes to creating a productive and efficient workplace. Several studies have focused on the importance of high levels of engagement in order to facilitate other outcomes, such as low absenteeism, high organisational commitment and employee wellness. Meaningful work is closely related to work engagement, and it is postulated that employees who experience meaningful work may display higher levels of work engagement (Dik \& Duffy, 2007).

This study will therefore attempt to shed light on the interaction of these variables by testing whether there are significant differences between the levels of engagement and the experience of meaningful work amongst different generational cohorts and what the relationship is between them. The research will therefore attempt to answer the following questions:

- Question 1: Is there a positive relationship between work engagement and meaningful work?

- Question 2: Are there significant differences between the generational cohorts in terms of meaningful work?
- Question 3: Are there significant differences between the generational cohorts in terms of work engagement?

\section{Research method}

\section{Sampling procedures}

Participants were selected by using non-probability stratified sampling from organisations within Gauteng, South Africa, to ensure a sufficient number of respondents for each generational cohort.

As work engagement levels were to be measured, individuals who had been working for one year or longer within the organisation needed to be included to allow for reasonable levels of engagement and meaningfulness.

The questionnaire consisted of three parts, including biographic information, the Utrecht Work Engagement Scale (UWES) developed by Schaufeli and Bakker (2003) and the Psychological Meaningfulness Scale (PMS) developed by Tymon (1988).

A total of 320 questionnaires were distributed, out of which 283 were returned (88\% response rate). After data vetting processes, 261 surveys (82\%) were identified as viable for the purposes of the analysis. Twenty-two cases (7\%) were excluded due to incomplete data, or work experience of less than one year.

Whilst questions relating to all three dimensions in the UWES were included, it is assumed that all items relate to engagement, which allowed unidimensional use of the instrument, an approach endorsed by several other authors (De Bruin, Hill, Henn \& Muller, 2013; Rothmann, Jorgensen \& Hill, 2011).

\section{Ethical considerations}

In any research project, ethical dimensions need to be considered. All participants in this study were included on the basis that they were fully briefed on the purpose of the project. Participation was voluntary and individuals had the opportunity to withdraw at any time. Furthermore, no participant's name was included in the study: responses were only labelled in terms of a numbering system. Organisations were also not explicitly mentioned, as the data were handled in a consolidated manner. In terms of data coding, each company was assigned an alpha character to ensure full anonymity.

\section{Results \\ Descriptive statistics}

Descriptive statistics were calculated in order to provide more information about the sample and to determine whether assumption-related violations existed (see Table 1).

In terms of the generational cohorts, participants belonged to one of three groups, depending on their year of birth. Participants born between the years 1946 and 1964 were grouped into the cohort labelled Baby Boomers, participants 
TABLE 1: Demographic characteristics of participants.

\begin{tabular}{|c|c|c|c|}
\hline Item & Characteristic & Frequency & Percentage \\
\hline \multirow[t]{2}{*}{ Gender } & Male & 128 & 49 \\
\hline & Female & 133 & 51 \\
\hline \multirow[t]{5}{*}{ Ethnicity } & Black & 60 & 23 \\
\hline & Mixed race & 15 & 5.7 \\
\hline & Indian/Asian & 14 & 5.4 \\
\hline & White & 170 & 65.1 \\
\hline & Missing/Invalid & 1 & 0.8 \\
\hline \multirow[t]{8}{*}{ Marital status } & Married (Civil) & 128 & 49.6 \\
\hline & Married (Traditional) & 18 & 7 \\
\hline & Polygamous marriage & 1 & 0.4 \\
\hline & Living with partner & 15 & 5.8 \\
\hline & Never married & 62 & 24 \\
\hline & Widow/Widower & 8 & 3.1 \\
\hline & Separated & 2 & 0.8 \\
\hline & Divorced & 24 & 9.3 \\
\hline \multirow[t]{4}{*}{ Employment status } & Permanent & 220 & 84.3 \\
\hline & Temporary & 7 & 2.7 \\
\hline & Contract & 33 & 12.6 \\
\hline & Missing & 1 & 0.4 \\
\hline \multirow{15}{*}{$\begin{array}{l}\text { Organisational } \\
\text { hierarchy }\end{array}$} & Administrative & 64 & 24.9 \\
\hline & Craft/Trade & 2 & 0.8 \\
\hline & Support services & 2 & 0.8 \\
\hline & Management & 47 & 18.3 \\
\hline & Technical & 14 & 5.4 \\
\hline & Legal & 7 & 2.7 \\
\hline & Marketing and sales & 10 & 3.9 \\
\hline & Human resources & 6 & 2.3 \\
\hline & Financial & 33 & 12.8 \\
\hline & Information technology & 34 & 13.2 \\
\hline & Purchasing/Tenders & 4 & 1.6 \\
\hline & Inventory & 1 & 0.4 \\
\hline & Quality assurance & 10 & 3.9 \\
\hline & Customer services & 12 & 4.7 \\
\hline & Other & 11 & 4.3 \\
\hline
\end{tabular}

TABLE 2: Generational cohorts.

\begin{tabular}{llcc}
\hline Year of birth & Generational cohort & Frequency & Percentage \\
\hline $1946-1964$ & Baby Boomers & 64 & 24.52 \\
$1965-1980$ & Generation X & 93 & 35.63 \\
$1981-1999$ & Generation Y & 104 & 39.85 \\
\hline
\end{tabular}

$N=261$.

TABLE 3: Skewness and kurtosis.

\begin{tabular}{lcc}
\hline Variable & Skewness & Kurtosis \\
\hline Engagement & -0.31 & -0.48 \\
Meaningful work & -0.4 & -0.56 \\
Age & -0.26 & -1.4 \\
\hline
\end{tabular}

born between 1965 and 1980 were allocated to the Generation X cohort and participants born between 1981 and 1999 were classified as Generation Y. The mean age for Baby Boomers, Generation X and Generation $Y$ were 57, 42 and 28 respectively and can be seen in Table 2 .

\section{Normality of distribution}

The data was scrutinised for any violations in terms of outliers, skewness and kurtosis levels. Although some level of skewness existed (Table 3), scores were acceptable for the size of the sample (Tabachnick \& Fidell, 2006).

\section{Reliability}

The commonly-used indicator for reliability is the Cronbach's alpha coefficient, which is considered acceptable when above 0.70 and preferably above 0.80 (Field, 2009; Pallant, 2005; Tabachnick \& Fidell, 2006).

Cronbach's alpha scores of 0.93 and 0.72 were obtained for the UWES and PMS respectively. In the case of the PMS one should take into consideration that reliability also tends to be lower when a scale consists of fewer than 10 items (Pallant, 2005).

\section{Correlation}

In order to examine the relationship between work engagement and meaningful work, Pearson's correlation coefficient was calculated. A moderate, positive correlation of 0.43 and statistical significance at the 0.01 level were achieved, indicating that higher levels of engagement can be associated with higher levels of meaningful work.

\section{Multivariate analysis of variance}

In order to understand how generational membership affects engagement and meaningfulness, a multivariate analysis of variance (MANOVA) was conducted. MANOVA, as opposed to multiple analysis of variance (ANOVAs) was chosen to avoid Type I errors and to show potential interaction effects.

To determine whether the assumption of homogeneity of variance-covariance matrices are adhered to, the Box Test was included in the analysis. According to the results (Significant value 0.782 ), it can be assumed that the homogeneity assumption has not been violated, as it presents larger than 0.001 (Pallant, 2005).

According to the Levene test, a significance value of less than 0.05 indicates violation of the assumptions of equality of variance. The Levene scores for work engagement and psychological meaningfulness respectively were 0.649 and 0.714 , indicating no related issues.

The results of the multivariate tests (Table 4) indicated that significant differences were present between the groups in terms of the dependant variables. For smaller sample sizes or groups with unequal sizes, the Pillai's trace is often the preferable measure and offers the best protection against Type I errors (Field, 2009). It can be assumed that a difference exists between the cohorts in terms of the relationship between engagement and meaningfulness.

Significance in terms of each of the variables were further investigated (test of between-subjects effects, Table 5).

The Baby Boomer cohort obtained the highest level of engagement (79.85), Generation X scored the second highest (74.13) and the Generation Y cohort scored the lowest (70.71). 
TABLE 4: Multivariate analysis.

\begin{tabular}{lccccc}
\hline Multivariate measure & Value & $\boldsymbol{F}$ & Hypothesis $\boldsymbol{d f}$ & Error $\boldsymbol{d f}$ & Significance \\
\hline Pillai's trace & 0.104 & 6.278 & 4 & 460 & 0 \\
Wilks's lambda & 0.897 & 6.420 & 4 & 458 & 0 \\
Hotelling's trace & 0.115 & 6.560 & 4 & 456 & 0.052 \\
Roy's largest root & 0.113 & 13.047 & 2 & 230 & 0.053 \\
\hline
\end{tabular}

TABLE 5: Estimated marginal means.

\begin{tabular}{lll}
\hline Variable & Cohort & Mean \\
\hline Engagement & Baby Boomers & 79.85 \\
& Generation X & 74.13 \\
Meaningfulness & Generation Y & 70.71 \\
& Baby Boomers & 15.35 \\
& Generation X & 14.78 \\
& Generation Y & 14.07 \\
\hline
\end{tabular}

When the meaningfulness levels are studied, the same pattern emerges. The Baby Boomers have the highest level of meaningfulness (15.35), Generation X members present with the second highest level (14.78) and Generation Y members have the lowest levels of the three cohorts (14.07).

Differences in themselves might not always have statistical significance. In order to determine whether there are significant differences between the groups, post hoc tests were executed (Table 6).

The multivariate tests, the Pillai's trace and Wilks's lambda values of 0.000 for both indicate that the differences were significant. In terms of engagement, there are significant differences between the Baby Boomer generation and the other two cohorts, whilst no significant difference is present between Generation X and Generation Y.

When meaningfulness is considered, a significant difference is present between Baby Boomers and Generation Y, but no significant variances are found between the Generation $X$ and Generation $Y$ members, or between members of the Baby Boomer and Generation $X$ cohorts. To understand the differences between the groups in more practical terms and to determine the effect size of the differences, Cohen's $d$ was calculated for each cohort for engagement and meaningful work respectively. The results can be seen in Table 7 .

\section{Discussion}

The purpose of this study was to investigate the relationship between work engagement and meaningful work and to compare levels of engagement and meaningfulness across different generational cohorts in the workplace.

Based on the results of the study, the findings in terms of each research question are discussed further.

\section{Question 1}

\section{Is there a positive relationship between meaningful work and engagement?}

As discussed, many authors support the idea that a relationship exists between meaningful work and engagement
(Anitha, 2014; Dullien, 2012; Fairlie, 2011; Kahn, 1990; Macey \& Schneider, 2008; Wells-Lepley, 2013). According to the results of this study, a moderate positive relationship exists between the two variables. This implies that higher levels of meaningful work could imply higher engagement levels, which could prompt organisations to pay more attention to the content of work and other factors such as person-job fit, again taking into consideration factors such as age, career stages and second careers.

\section{Question 2}

\section{Are there significant differences between the generational cohorts in terms of meaningful work?}

One of the main gaps identified by previous research is inconclusive evidence on whether there are any real differences in the experience of meaningful work between the generational cohorts (Boone-James et al., 2011; Drake, 2012; Kapoor \& Solomon, 2011; Kunreuther, 2003; Overell, 2008).

In terms of meaningful work, this study presented only a significant difference between Baby Boomers and Generation Y. If one takes the theory into account that each cohort will conceptualise meaning in work differently according to the life stage that they are in and that meaning will change as more experience is gained (Boone-James et al., 2011; Glass, 2007; Miller, 2008), the results can partially be accounted for as the differences between Generation X and Baby Boomers are a lot less pronounced. Perhaps the segmentation of generational cohorts should also be scrutinised in finer detail to improve the richness of the data.

\section{Question 3}

Are there significant differences between the generational cohorts in terms of engagement?

As with the case of meaningful work, global studies deliver conflicting results when it comes to the engagements levels of generational cohorts in the workplace. The results of this study indicated a significant difference between the Baby Boomer generation and the other two cohorts, but no significant difference between Generation $X$ and Generation Y. Baby Boomers are the most engaged, supporting results found by Coetzee and De Villiers (2010). This also supports other international studies who indicated similar trends (AON Hewitt, 2013; Australian Public Service Commission, 2012).

The differences in engagement levels between the cohorts could be attributed to various factors. If Baby Boomers are highly ambitious, competitive, dedicated and driven 
TABLE 6: Post hoc tests.

\begin{tabular}{|c|c|c|c|c|c|c|c|c|}
\hline \multirow[t]{2}{*}{ Variable } & \multirow{2}{*}{$\begin{array}{l}\text { Multivariate } \\
\text { measure }\end{array}$} & \multirow[t]{2}{*}{ (I) Cohort } & \multirow[t]{2}{*}{ (J) Cohort } & \multirow[t]{2}{*}{ Mean difference } & \multirow[t]{2}{*}{ Standard error } & \multirow[t]{2}{*}{ Significance } & \multicolumn{2}{|c|}{$95 \%$ confidence interval } \\
\hline & & & & & & & Lower bound & Upper bound \\
\hline \multirow[t]{23}{*}{ Engagement } & Tukey HSD & Baby Boomers & Generation X & $5.7123^{*}$ & 2.06293 & 0.017 & 0.8459 & 10.5787 \\
\hline & & & Generation Y & $9.1383 *$ & 2.02100 & 0.000 & 4.3708 & 13.9058 \\
\hline & & Generation X & Baby Boomers & $-5.7123 *$ & 2.06293 & 0.017 & -10.5787 & -0.8459 \\
\hline & & & Generation $Y$ & 3.426 & 1.82479 & 0.148 & -0.8787 & 7.7307 \\
\hline & & Generation Y & Baby Boomers & $-9.1383^{*}$ & 2.02100 & 0.000 & -13.9058 & -4.3708 \\
\hline & & & Generation X & -3.426 & 1.82479 & 0.148 & -7.7307 & 0.8787 \\
\hline & Scheffe & Baby Boomers & Generation X & $5.7123 *$ & 2.06293 & 0.023 & 0.6297 & 10.7949 \\
\hline & & & Generation $Y$ & $9.1383^{*}$ & 2.02100 & 0.000 & 4.1590 & 14.1176 \\
\hline & & Generation X & Baby Boomers & $-5.7123 *$ & 2.06293 & 0.023 & -10.7949 & -0.6297 \\
\hline & & & Generation $Y$ & 3.426 & 1.82479 & 0.174 & -1.0699 & 7.9219 \\
\hline & & Generation $Y$ & Baby Boomers & $-9.1383 *$ & 2.02100 & 0.000 & -14.1176 & -4.1590 \\
\hline & & & Generation X & -3.426 & 1.82479 & 0.174 & -7.9219 & 1.0699 \\
\hline & LSD & Baby Boomers & Generation X & $5.7123^{*}$ & 2.06293 & 0.006 & 1.6476 & 9.7770 \\
\hline & & Generation X & Baby Boomers & $-5.7123^{*}$ & 2.06293 & 0.006 & -9.7770 & -1.6476 \\
\hline & & & Generation $Y$ & 3.426 & 1.82479 & 0.062 & -0.1694 & 7.0215 \\
\hline & & Generation Y & Baby Boomers & $-9.1383^{*}$ & 2.02100 & 0.000 & -13.1203 & -5.1563 \\
\hline & & & Generation X & -3.426 & 1.82479 & 0.062 & -7.0215 & 0.1694 \\
\hline & Bonferroni & Baby Boomers & Generation X & $5.7123^{*}$ & 2.06293 & 0.018 & 0.7373 & 10.6873 \\
\hline & & & Generation $Y$ & $9.1383^{*}$ & 2.02100 & 0.000 & 4.2644 & 14.0122 \\
\hline & & Generation X & Baby Boomers & $-5.7123^{*}$ & 2.06293 & 0.018 & -10.6873 & -0.7373 \\
\hline & & & Generation $Y$ & 3.426 & 1.82479 & 0.185 & -0.9747 & 7.8267 \\
\hline & & Generation Y & Baby Boomers & $-9.1383^{*}$ & 2.02100 & 0.000 & -14.0122 & -4.2644 \\
\hline & & & Generation X & -3.426 & 1.82479 & 0.185 & -7.8267 & 0.9747 \\
\hline \multirow[t]{22}{*}{ Meaningfulness } & Tukey HSD & Baby Boomers & Generation X & 0.5617 & .43425 & 0.400 & -0.4627 & 1.5861 \\
\hline & & & Generation $\mathrm{Y}$ & $1.2796 *$ & .42543 & 0.008 & 0.2760 & 2.2832 \\
\hline & & Generation X & Baby Boomers & -0.5617 & .43425 & 0.400 & -1.5861 & 0.4627 \\
\hline & & & Generation $Y$ & 0.7179 & .38412 & 0.150 & -0.1882 & 1.6241 \\
\hline & Scheffe & Baby Boomers & Generation X & 0.5617 & .43425 & 0.435 & -0.5082 & 1.6316 \\
\hline & & & Generation $Y$ & $1.2796 *$ & .42543 & 0.012 & 0.2315 & 2.3278 \\
\hline & & Generation X & Baby Boomers & -0.5617 & .43425 & 0.435 & -1.6316 & 0.5082 \\
\hline & & & Generation $Y$ & 0.7179 & .38412 & 0.177 & -0.2285 & 1.6643 \\
\hline & & Generation $Y$ & Baby Boomers & $-1.2796 *$ & .42543 & 0.012 & -2.3278 & -0.2315 \\
\hline & & & Generation X & -0.7179 & .38412 & 0.177 & -1.6643 & 0.2285 \\
\hline & LSD & Baby Boomers & Generation X & 0.5617 & .43425 & 0.197 & -0.2939 & 1.4173 \\
\hline & & & Generation $Y$ & $1.2796 *$ & .42543 & 0.003 & 0.4414 & 2.1178 \\
\hline & & Generation X & Baby Boomers & -0.5617 & .43425 & 0.197 & -1.4173 & 0.2939 \\
\hline & & & Generation $Y$ & 0.7179 & .38412 & 0.063 & -0.0389 & 1.4748 \\
\hline & & Generation Y & Baby Boomers & $-1.2796 *$ & .42543 & 0.003 & -2.1178 & -0.4414 \\
\hline & & & Generation X & -0.7179 & .38412 & 0.063 & -1.4748 & 0.0389 \\
\hline & Bonferroni & Baby Boomers & Generation X & 0.5617 & .43425 & 0.591 & -0.4856 & 1.6089 \\
\hline & & & Generation $Y$ & $1.2796 *$ & .42543 & 0.009 & 0.2536 & 2.3056 \\
\hline & & Generation X & Baby Boomers & -0.5617 & .43425 & 0.591 & -1.6089 & 0.4856 \\
\hline & & & Generation $Y$ & 0.7179 & .38412 & 0.189 & -0.2084 & 1.6443 \\
\hline & & Generation Y & Baby Boomers & $-1.2796^{*}$ & .42543 & 0.009 & -2.3056 & -0.2536 \\
\hline & & & Generation X & -0.7179 & .38412 & 0.189 & -1.6443 & 0.2084 \\
\hline
\end{tabular}

Note: Based on observed means. The error term is mean square (error) $=6.438$

*, The mean difference is significant at the 0.05 level.

(Drewery, Riley \& Staff, 2008; Hornbostel et al., 2011; White, 2011), it can be inferred that they might be more engaged in their work in order to reach their goals. The differences can be attributed to the different generational experiences that impact on behaviour (Glass, 2007). One can also not completely rule out other that factors such as personality factors and temperament that may have contributed to some of the observed differences (Langelaan, Bakker, Van Doornen \& Schaufeli, 2006), although the focus of the study was not on individual differences but on differences between generational cohorts.

\section{Implications for organisations}

The changing generational landscape can be taken into consideration when the engagement levels of the cohorts are interpreted from this study, as it provides an additional contextual background. As employees within the workforce mature, the distribution of the generational cohorts is 
TABLE 7: Effect size (Cohen's $d$ ) for differences between groups for engagement and meaningful work.

\begin{tabular}{|c|c|c|}
\hline Variable & Cohen's $d$ & Cohort \\
\hline \multirow[t]{6}{*}{ Work Engagement } & 0.50 & Baby Boomers \\
\hline & & Gen $X$ \\
\hline & 0.64 & Baby Boomers \\
\hline & & Gen $Y$ \\
\hline & 0.14 & Gen X \\
\hline & & Gen $Y$ \\
\hline \multirow[t]{6}{*}{ Meaningful work } & 0.46 & Baby Boomers \\
\hline & & Gen X \\
\hline & 0.56 & Baby Boomers \\
\hline & & Gen $Y$ \\
\hline & 0.01 & Gen $X$ \\
\hline & & Gen $Y$ \\
\hline
\end{tabular}

changing. According to Mlodzik and De Meuse (2010), the estimated generational stratification for 2010 and beyond in the USA is as follows: $5 \%$ Matures (the generation preceding the Baby Boomers), 38\% Baby Boomers, 32\% Generation X and $25 \%$ Generation Y. Future predictions indicate that by 2020 , Generation $Y$ will be the predominant cohort (42\% of the workforce), whilst Generation $X$ will remain relatively stable at $30 \%$. The Mature cohort will be reduced to $1 \%$ of the workforce, whilst Baby Boomers will represent 22\% and a new cohort will be introduced in the form of Generation $\mathrm{Z}$ (Mlodzik \& De Meuse, 2010).

In today's workplace, members from the older cohorts are not necessarily leaving the workforce once they reach retirement age. In the current financial climate, people continue to work well beyond retirement age to enable a more comfortable lifestyle. For this reason, it is important to facilitate higher engagement levels amongst older employees (Hornbostel et al., 2011). Benchmark surveys have indicated that $60 \%$ of South African pensioners appear to be in financial crisis and $31 \%$ continued some form of employment after their official retirement date to supplement their income (Sanlam, 2013).

The results of the study indicate that Baby Boomers are the most engaged, and this finding has various implications. Firstly, it could be projected that organisations within South Africa might risk losing the most engaged cohort in the near future. This also has another implication, which is that the larger part of the workforce might not be optimally engaged. According to studies, the impact of less engaged employees could translate into large financial losses (Bates, 2004; Gallup Consulting, 2008). Organisations should therefore attempt to understand how engagement levels could affect their organisational success and act accordingly.

\section{Limitations}

Some limitations should be noted. Common method bias may have influenced the results as respondents were asked to respond to more than one construct in the same survey at the same time. With smaller sample sizes, any significant differences between groups should be treated with caution. The Baby Boomers cohort was a much smaller group than the other two cohorts which could have influenced the results.
This also poses a problem in terms of generalisability of the results.

Perhaps one of the downfalls of using well- established instruments is that one sometimes assumes that they remain relevant over time. Significant differences between Baby Boomers and Generation Y could, besides others factors, also be attributed to test item bias, simply having a different understanding or interpretation of the constructs being measured. Differential item functioning (Karami, 2012) is recommended to address this shortcoming. Another possible cause that could have been overlooked in explaining at least some of the differences is the use of composite scores in analysing mean differences between groups (Steinmetz, 2013). According to Steinmetz (2013), researchers in social sciences often assume that partial invariance of the measurement instrument is sufficient, which might not be the case when working with composite scores. Results should therefore be treated with care.

\section{Recommendations}

Within the diverse and changing landscape in the workplace, the focus of many organisations needs to start shifting towards the needs and values of different generational cohorts. The fact that Baby Boomers outperformed Generation $X$ and Generation $Y$ in terms of both work engagement and meaningful work indicates that they have a lot more to offer than what stereotypically has been believed. Whilst this study provides relevant information in terms of the engagement and meaningful work levels between the cohorts, more in-depth research is required to enable organisations to customise better engagement strategies.

It would for instance be interesting to investigate the engagement levels over time, to determine whether these vary for the same participants across a specific time period. Furthermore, it is recommended that more is done to understand how different generations approach meaningful work and whether the same definitions are present across different cohorts. This could aid organisations to tailor their selection, development and reward policies to suit individuals from different age groups.

Attention could be paid to the interaction between the different generations in the workforce to determine whether the groups experiencing higher levels of engagement and meaningfulness could ultimately play a role in elevating these levels amongst the other groups. It is further suggested that more in-depth mixed approaches such as qualitative and longitudinal studies should investigate other factors such as personality differences across generational cohorts and the influences of the different career stages on the experience of work.

\section{Conclusion}

This study showed that a positive moderate relationship exists between work engagement and meaningful work and 
that efforts to increase engagement levels will have a positive effect on workers' experiences of meaningfulness in their work. Beliefs that older people are less engaged and find work less meaningful are proven incorrect. In both instances, Baby Boomers outperformed their younger counterparts. The results therefore suggest that organisations should take age into serious consideration when designing their engagement strategies. With people retiring later, organisations need to keep their older workers engaged, but also need to determine which elements the other generational cohorts find meaningful in their work to become more engaged and customise their strategies accordingly.

\section{Acknowledgements Competing interests}

The authors declare that they have no financial or personal relationship(s) that may have inappropriately influenced them in writing this article.

\section{Authors' contributions}

C.H. (University of Johannesburg) was the supervisor of the research study. She was responsible for making conceptual contributions to the study and contributed to updating and revising the literature review, executing the data analysis and writing the article. J.B. (University of Johannesburg) was responsible for conceptual contributions to the study; she was the main contributor to the literature review and was responsible for data collection and data capturing.

\section{References}

Anitha, J. (2014). Determinants of employee engagement and their impact on employee performance. International Journal of Productivity and Performance Management, 63(3), 308-323. http://dx.doi.org/10.1108/IJPPM-01-2013-0008

AON Hewitt. (2013). 2013 trends in global employee engagement. Retrieved February 14, 2014, from http://www.aon.com/forms/2013/AH_trendsemployee-engagement.html

Australian Public Service Commission. (2012). Employee engagement. Retrieved February 16, 2014, from http://www.apsc.gov.au/about-the-apsc/parliamentary/ state-of-the-service/2011-12-sosr/04-employee-engagement

Ayers, D.F., Miller-Dyce, C., \& Carlone, D. (2008). Security, dignity, caring relationships and meaningful work: Needs motivating participation in a jobtraining program. Community College Review, 35(4), 257-276. http://dx.doi. org/10.1177/1059601108314581

Bakker, A.B., \& Demerouti, E. (2008). Towards a model of work engagement Career Development International, 13, 209-223. http://dx.doi.org/10.1108/ 13620430810870476

Bakker, A.B., \& Schaufeli, W.B. (2008). Positive organizational behaviour: Engaged employees in flourishing organizations. Journal of Organizational Behaviour, 29 147-154. http://dx.doi.org/10.1002/job.515

Bakker, A.B., Xanthopoulou, D., Dollard, M.F., Demerouti, E., Schaufeli, W.B., Taris, T.W. et al. (2007). When do job demands particularly predict burnout? The moderating
role of job resources. Journal of Managerial Psychology, 22(8), 766-786. http:// role of job resources. Journal of Managerial
dx.doi.org/10.1108/02683940710837714

Bates, S. (2004). Getting engaged. HR Magazine, 49(2), 44-51. Retrieved from http:// www.shrm.org/publications/hrmagazine/editorialcontent/pages/0204covstory. aspx

BlessingWhite. (2012). The engagement equation. Retrieved February 04, 2014, from http://blessingwhite.com/elibrary/eEngagement_Equation_FactSheet.pdf

Boone-James, J., Mckechnie, S., \& Swanberg, J. (2011). Predicting employee engagement in an age-diverse retail workforce. Journal of Organizational Behaviour, 32, 173-196. http://dx.doi.org/10.1002/job.681

Bowie, N.E. (1998). A Kantian theory of meaningful work. Journal of Business Ethics, 17(9-10), 1083-1092. http://dx.doi.org/10.1023/A:1006023500585

Chalofsky, N., \& Krishna, V. (2009). Meaningfulness, commitment, and engagement: The intersection of a deeper level of intrinsic motivation. Advances in Developing Human Resources, 11(2), 189-203. http://dx.doi.org/10.1177/1523422309333147
Coetzee, M., \& De Villiers, M. (2010). Sources of job stress, work engagement and career orientations of employees in a South African financial institution. South career orientations of employees in a

Crabtree, S. (2005). Engagement keeps the doctor away. Gallup Management Journal. Retrieved February 15, 2014, from http://nsuweb.nova.edu/ie/ice/forms/ engagement_keeps_the_doctor_away.pdf

Csikszentmihalyi, M. (1975). Beyond boredom and anxiety. Retrieved March 20, 2014 from http://pages.ucsd.edu/ nchristenfeld/Happiness_Readings_files/Class $\% 20$ 7\%20-\%20Csikszentmihalyi\%201975.pdf

D'Amato, A., \& Herzfeldt, R. (2008). Learning orientation, organizational commitment and talent retention across generations: A study of European managers. Journal of Managerial Psychology, 23(8), 929-953. http://dx.doi. org/10.1108/02683940810904402

Deal, J.J., Altman, D.G., \& Rogelberg, S.G. (2010). Millennials at work: What we know and what we need to do (if anything). Journal of Business and Psychology, 25(2), 191-199. http://dx.doi.org/10.1007/s10869-010-9177-2

De Bruin, G.P., Hill, C., Henn, C.M., \& Muller, K. (2013). Dimensionality of the UWES17. An item response modeling analysis. SA Journal of Industrial Psychology, 39(2), 8 pages. http://dx.doi.org/10.4102/sajip.v39i2.1148

Dik, B.J., \& Duffy, R.D. (2007). Calling and vocation at work: Definitions and prospects for research and practice. The Counselling Psychologist, 37(3), 424-450. http:// dx.doi.org/10.1177/0011000008316430

Drake, T.J. (2012). Assessing employee engagement: A comparison of the job engagement scale and the Utrecht Work Engagement Scale. Retrieved June 16, engagement scale and the Utrecht Work Engagement Scale. Retrieved June 16, 2014, from http://digitool.library.colostate.edu/exlibris/dtl/d3_1/apache
L2V4bGlicmlzL2RObC9kM18xL2FwYWNoZV9tZWRpYS8xNzA3MzM=.pdf

Drewery, K., Riley, A. \& Staff, H. (2008). Genup-Howthefourgenerationswork. Retrieved February 15, 2014, from http://www.cipd.co.uk/NR/rdonlyres/25DA52DE-F1204579-AFE3-564C8801425D/0/genuphowfourgenerationswork.pdf

Dullien, T. (2012). Improving employee engagement: Make work meaningful. Indian Gaming, 31(3), 34-37.

Dwyer, R.J. (2009). Prepare for the impact of the multi-generational workforce! Transforming Government: People, Process and Policy, 3(2), 101-110. http:// dx.doi.org/10.1108/17506160910960513

Emergent Growth. (2013). Sub-Saharan Africa: Employee engagement survey. Retrieved February 10, 2014, from http://personal.crocodoc.com/ JpxHxFj?embedded=true

Erickson, T. (2011). Meaning is the new money. Retrieved March 20, 2014, from http://blogs.hbr.org/2011/03/challenging-our-deeply-held-as/

Evenson, L. (2014). New frontiers in employee engagement. Retrieved February 12, 2014, from http://www.bersin.com/News/Details.aspx?id=15208

Fairlie, P. (2011). Meaningful work, employee engagement, and other key employee outcomes: Implications for human resource development. Advances in Developing Human Resources, 13(4), 508-525. http://dx.doi. Advances in Developing Human
org/10.1177/1523422311431679

Field, A. (2009). Discovering statistics using SPSS. London: SAGE Publications.

Frankl, V.E. (1984). Man's search for meaning: An introduction to logotherapy. Boston, MA: Beacon Press.

Gallup Consulting. (2008). Employee engagement: What is your engagement ratio? Retrieved March 18, 2014, from http://www.gallup.com/strategicconsulting/ 121535/Employee-Engagement-Overview-Brochure.aspx

Glass, A. (2007). Understanding generational differences for competitive success. Industrial and Commercial Training, 39(2), 98-103. http://dx.doi.org/10.1108/ 00197850710732424

Hallberg, U., \& Schaufeli, W.B. (2006). 'Same same' but different? Can work engagement be discriminated from job involvement and organizational commitment? European Psychologist, 11, 119-127. http://dx.doi.org/10.1027/1016-9040.11.2.119

Havenga, W., Stanz, K., Visagie, J., \& Wait, K. (2011). Evaluating the difference in employee engagement before and after business and cultural transformation interventions. African Journal of Business Management, 5(22), 8804-8820. http:// interventions. African Journal of Busin
dx.doi.org/10.5897/AJBM10.1436

Hirschi, A. (2012). Callings and work engagement: Moderated mediation model of work meaningfulness, occupational identity, and occupational self-efficacy. Journal of Counseling Psychology, 59(3), 479-485. PMID: 22774870, http://dx.doi. Journal of Counseling Psych
org/10.1037/a0028949

Holbeche, L., \& Springett, N. (2003). In search of the meaning of work. Exeter: Roffey Park Institute.

Hornbostel, B., Kumar, R., \& Smith, R. (2011). My generation. Retrieved February 10, 2014, from http://research.microsoft.com/en-us/projects/thinkweek/fourgenerationshornbostel_kumar_smith-july2011.pdf

Kahn, W.A. (1990). Psychological conditions of personal engagement and disengagement at work. Academy of Management Journal, 33(4), 692-724. Retrieved from http://www.jstor.org/stable/256287

Kapoor, C., \& Solomon, N. (2011). Understanding and managing generational differences in the workplace. Worldwide Hospitality and Tourism Themes, 3(4), 308-318. http://dx.doi.org/10.1108/17554211111162435

Karami, H. (2012). An introduction to differential item functioning. The Internationa Journal of Educational and Psychological Assessment, 11(2), 59-75. Retrieved from http://www.academia.edu/1030760/An_introduction_to_Differential_Item Functioning

Kenexa. (2012). The many contexts of employee engagement. Retrieved February 10, 2014, from http://www.kenexa.com/Portals/0/Downloads/KHPI Papers/The Many Contexts of Employee Engagement-2012 WT Report_CS6.pdf 
King, L.A., \& Napa, C.K. (1998). What makes a life good? Journal of Personality and Social Psychology, 75(1), 156-165. PMID: 9686456, http://dx.doi. and Social Psychology, 75(1),
org/10.1037/0022-3514.75.1.156

Koloc, N. (2013). What job candidates really want: Meaningful work. Harvard Business Review. Retrieved March 16, 2014, from http://blogs.hbr.org/2013/04/what-jobcandidates-really-wan/

Kompier, M. (2005). Dealing with workplace stress. In C.L. Cooper (Ed.), Handbook of stress medicine and health (pp. 349-374). London: CRC Press.

Kowske, B.J., Rasch, R., \& Wiley, J. (2010). Millennials' (lack of) attitude problem: An empirical examination of generational effects on work attitudes. Journal of Busines and Psychology, 25(2), 265-279. http://dx.doi.org/10.1007/s10869-010-9171-8

Kular, S., Gatenby, M., Rees, C., Soane, E., \& Truss, K. (2008). Employee engagement: A literature review. Retrieved March 16, 2014, from http://eprints.kingston. ac.uk/4192/1/19wempen.pdf

Kunreuther, F. (2003). The changing of the guard: What generational differences tell us about social-change organizations. Nonprofit and Voluntary Sector Quarterly, 32(3), 450-457. http://dx.doi.org/10.1177/0899764003254975

Langelaan, S., Bakker, A.B., Van Doornen, L.J., \& Schaufeli, W.B. (2006). Burnout and work engagement: Do individual differences make a difference? Personality and Individual Differences, 40(3), 521-532. http://dx.doi.org/10.1016/j. paid.2005.07.009

Lips-Wiersema, M., \& Wright, S. (2012). Measuring the meaning of meaningful work: Development and validation of the Comprehensive Meaningful Work Scale (CMWS). Group \& Organization Management, 37(5), 655-685. http://dx.doi. org/10.1177/1059601112461578

Macey, W.H., \& Schneider, B. (2008). The meaning of employee engagement. Industrial and Organizational Psychology, 1(1), 3-30. http://dx.doi.org/10.1111/ j.1754-9434.2007.0002.x

Maslach, C., \& Leiter, M.P. (1997). Early predictors of job burnout and engagement. Journal of Applied Psychology, 93(3), 498-512. http://dx.doi.org/10.1037/0021 9010.93.3.498

Maslach, C., Schaufeli, W.B., \& Leiter, M.P. (2001). Job burnout. Annual Review of Psychology, 53, 397-422.

Maslow, A.H. (1943). A theory of human motivation. Psychological Review, 50, 370-396.

Maurer, R. (2013). Employee engagement high in Sub-Saharan Africa. Retrieved February 13, 2014, from http://www.shrm.org/hrdisciplines/global/articles/ February 13, 2014, from http://www.shr
pages/employee-engagement-high-africa.aspx

May, D.R., Gilson, R.L., \& Harter, L.M. (2004). The psychological conditions of meaningfulness, safety and availability and the engagement of the human spirit at work. Journal of Occupational and Organizational Psychology, 77(1), 11-37. http://dx.doi.org/10.1348/096317904322915892

Meriac, J.P., Woehr, D.J., \& Banister, C. (2010). Generational differences in work ethic: An examination of measurement equivalence across three cohorts. Journal of Busines and Psychology, 25(2), 315-324. http://dx.doi.org/10.1007/s10869-010-9164-7

Miller, B., \& Nyce, S. (2014). Which workers are delaying retirement and why? Retrieved October 12, 2014, from http://www.towerswatson.com/en/Insights/Newsletters/ Americas/Insider/2014/which-employees-are-delaying-retirement-and-why

Miller, C.S. (2008). Meaningful work over the life course. Fielding Graduate University. Retrieved March 15, 2014, from http://0-search.proquest.com.ujlink.uj.ac.za/ pqdtglobal/docview/304823090/6D5CD4C186E44944PQ/1?accountid=13425

Mlodzik, K.J., \& De Meuse, K. (2010). A scholarly investigation of generational workforce differences: Debunking the myths. Retrieved March 20, 2014, from http:// www.ihrim.org/Pubonline/Wire/Sept12/ScholarlylnvestigationofGenerationa WorkforceDifferences.pdf

Morrow, P.C. (1983). Concept redundancy in organizational research: The case of work commitment. Academy of Management Review, 8(3), 486-500. http://dx.doi. org/10.5465/AMR.1983.4284606

Olivier, A.L., \& Rothmann, S. (2007). Antecedents of work engagement in multinational oil company. SA Journal of Industrial Psychology, 33(3), 49-56. http://dx.doi.org/10.4102/sajip.v33i3.396

Overell, S. (2008). Inwardness: The rise of meaningful work. London: The Work Foundation. Retrieved from http://www.theworkfoundation.com/assets/docs/ publications/32_inwardness_final.pdf

Pallant, J. (2005). SPSS survival manual. Crows Nest: Allen \& Unwin.

Parry, E., \& Urwin, P. (2009). Tapping into talent. Retrieved February10,2014, from http:// employeeengagement.com/wp-content/uploads/2010/08/Tappingintotalent FINAL.pdf

Pech, R., \& Slade, B. (2006). Employee disengagement: Is there evidence of a growing problem? Handbook of Business Strategy, 7(1), 21-25. http://dx.doi. org/10.1108/10775730610618585
Pitt-Catsouphes, M., \& Matz-Costa, C. (2009). Engaging the 21st century multigenerational workforce. Retrieved February 10, 2014, from http://www.bc.edu/ generational workforce. Retrieved February 10, 2014,
research/agingandwork/projects/generations.html

Robinson, D., Perryman, S., \& Hayday, S. (2004). The drivers of employee engagement. Retrieved February 10, 2014, from http://www.employment-studies.co.uk/pubs/ summary.php?id=408

Roodt, G. (2004). Concept redundancy and contamination in employee commitment research: Current problems and future directions. SA Journal of Industria Psychology, 30(1), 82-90. http://dx.doi.org/10.4102/sajip.v30i1.135

Rothmann, S. (2003). Burnout and engagement: A South African perspective. SA Journal of Industrial Psychology, 29(4), 16-25. http://dx.doi.org/10.4102/sajip. v29i4.121

Rothmann, S., Jorgensen, L.I., \& Hill, C. (2011). Coping and work engagement in selected South African organisations. SA Journal of Industrial Psychology, 37(1) 107-117. http://dx.doi.org/10.4102/sajip.v37i1.962

Rothmann, S., \& Rothmann, S. (2010). Factors associated with employee engagement in South Africa. SA Journal of Industrial Psychology, 36(2), 27-38. http://dx.doi. org/10.4102/sajip.v36i2.925

Sanlam. (2013). When one day becomes day one. Retrieved March 20, 2014, from http://www.sanlambenchmark.co.za/webadmin/include/content/2013 PENSIONER 8 May FINAL.pdf

Schaufeli, W.B. (2013). What is engagement? In C. Truss, K. Alfes, R. Delbridge, A Shantz, \& E. Soane (Eds.), Employee engagement in theory and practice (pp. 15-35) London: Routledge.

Schaufeli, W., \& Bakker, A. (2003). UWES Utrecht Work Engagement Scale. Retrieved March 19, 2014, from http://www.beanmanaged.com/doc/pdf/arnoldbakker/ articles/articles_arnold_bakker_87.pdf

Schaufeli, W.B., Salanova, M., Gonzáles-Romá, V., \& Bakker, A.B. (2002). The measurement of engagement and burnout: A two sample confirmatory factor analytic approach. Journal of Happiness Studies, 3, 71-92.

Schaufeli, W.B., Taris, T.W., \& Van Rhenen, W. (2008). Workaholism, burnout, and work engagement: Three of a kind or three different kinds of employee wellbeing? Applied Psychology, 57(2), 173-203. http://dx.doi.org/10.1111/j.14640597.2007.00285.x

Schewe, C.D., \& Noble, S.M. (2000). Market segmentation by cohorts: The value and validity of cohorts in America and abroad. Journal of Marketing Management, 16(1-3), 129-142. http://dx.doi.org/10.1362/026725700785100479

Scott, D., \& McMullen, T. (2010). The impact of rewards programs on employee engagement. Retrieved March 18, 2014, from http://www.worldatwork.org/ waw/adimLink?id=39032

Seligman, E.P., \& Csikszentmihalyi, M. (2000). Positive psychology: An introduction. American Psychologist, 55(1), 5-14. http://dx.doi.org/10.1037//0003-066X.55.1.5

Sonnentag, S. (2011). Research on work engagement is well and alive. European Journal of Work and Organizational Psychology, 20(1), 29-38. http://dx.doi.org/1 $0.1080 / 1359432 \times .2010 .510639$

Steinmetz, H. (2013). Analyzing observed composite differences across groups: Is partial measurement invariance enough? Methodology: European Journal of Research Methods for the Behavioral and Social Sciences, 9(1), 1-12. http:// Research Methods for the Behavioral and
dx.doi.org/10.1027/1614-2241/a000049

Tabachnick, B.G., \& Fidell, L.S. (2006). Using multivariate statistics. (5th edn.). Boston, MA: Pearson.

Thomas, K.W., \& Velthouse, B.A. (1990). Cognitive elements of empowerment An 'interpretive' model of intrinsic task motivation. Academy of Management Review, 15(4), 666-681. http://dx.doi.org/10.5465/AMR.1990.4310926

Tymon, W.G. (1988). An empirical investigation of a cognitive model of empowerment. Temple University. Retrieved March 26, 2014, from http://0-search.proquest.com. ujlink.uj.ac.za/pqdtglobal/docview/303724939/fulltextPDF/

Wells-Lepley, M. (2013). Meaningful work: The key to employee engagement. Business Lexicon: Weekly Wire. Retrieved March 15, 2014, from http://bizlex. com/2013/03/meaningful-work-the-key-to-employee-engagement/

White, M. (2011). Rethinking generation gaps in the workplace: Focus on shared values. Retrieved February 10, 2014, from https://www.kenanflagler.unc.edu/executive-development/custom-programs/ /media/ C8FC09AEF03743BE91112418FEE286D0.ashx

Wong, M., Gardiner, E., Lang, W., \& Coulon, L. (2008). Generational differences in personality and motivation: Do they exist and what are the implications for the workplace? Journal of Managerial Psychology, 23(8), 878-890. http://dx.doi. org/10.1108/02683940810904376

Wrzesniewski, A., McCauley, C., Rozin, P., \& Schwartz, B. (1997). Jobs, careers, and callings: People's relations to their work. Journal of Research in Personality, 31 21-33. http://dx.doi.org/10.1006/jrpe.1997.2162 